\title{
INTEREST IN PURCHASING IN-GAME CONTENT BASED ON GAME CHARACTERISTICS AND INDONESIAN PLAYER BEHAVIOUR
}

\author{
Agung Riyadi ${ }^{1}$, Riwinoto ${ }^{2}$ \\ ${ }^{12}$ Jurusan Teknik Informatika, Politeknik Negeri Batam \\ Jl. Ahmad Yani, Teluk Tering, Kec. Batam Kota, Kota Batam, Kepulauan Riau 29461 \\ ${ }^{1}$ agunghakase@gmail.com, ${ }^{2}$ riwi@ polibatam.ac.id
}

\begin{abstract}
This research aimed to find out what games are currently being played and how many contents purchased in them. Information regarding the interest in purchasing the game contents is crucial for the game developers to determine the game type to be developed. The research used a survey method conducted on 455 respondents aged 18-30 years from Indonesia. The survey results stated that most Indonesian game players were in the Regular Player category who played Action games with a population of $71 \%$. The amount of interest in purchasing the contents from the Frequent Players towards Action and RPG games was $\mathbf{9 2 \%}$. As for games in the Puzzle category, the amount of interest in purchasing the contents was very small. $96 \%$ of puzzle game players certainly had no interest in purchasing the contents.
\end{abstract}

Keywords: Games, Association Rules, Virtual Currency

\section{INTRODUCTION}

The gaming industry in Indonesia has great potential to develop and compete in the international market through the creative industry. To accelerate the creative industry development, the Indonesian government through the Ministry of Industry and Creative Economy Agency (BEKRAF) in 2015 included the game and application development to be the first sector of the other 16 creative industry sectors [1]. In 2017, the Indonesian government proved that the role of the game and application development sector had increased by 1,93 percent of the gross domestic product in the creative economy sector in Indonesia.

The gaming industry can generate billions of dollars from the players [2]. In Indonesia, the gaming industry development is offset by an increase in the number of game players. Based on the research [3] conducted, the number of Indonesian game players in 2017 was around 43,7 million people. This was a huge potential for the industrial market.

The existence of government support and the increasing number of game players could trigger the growth of startups in the gaming sector in Indonesia. One of the forms of the government supports was to provide funding of 78 billion rupiah for 285 startups in the technology sector in 2018 [4].

However, the effort had not been able to ward off the potential startup failures. Based on the research, the startup failure worldwide was quite high, namely around 90\% [5]. Indonesian startups also had the same potential, including the startups in the gaming sector.
One of the efforts to keep the gaming startups afloat and growing is the income from the sales of the premium in-game contents offered to the gamers themselves. The gaming startups will continue to grow as long as their products are widely played and purchased by the gamers.

Therefore, the information about the player's interest in playing the games and interest in purchasing the premium contents is essential for the game developers, especially for the Indonesian game player's behavior, so that the creative industry in the gaming sector can grow.

\section{OBJECTIVE}

1. Provide information to the readers to understand how interest in purchasing the game contents made by the Indonesian game players based on the game characteristics, namely game type, game platform, and game mode.

2. Provide information to the readers about the interest in purchasing the contents of the Indonesian players to 3 groups of game players based on the playing duration, namely: Infrequent, Regular, and Frequent Player.

\section{LITERATURE REVIEW}

\section{A. Game Type dan Genre}

Game type also called gameplay is divided into 7 types, namely action, role playing, simulation, strategy, sport, puzzle, and idle games. In contrast, genre usually describes how to tell a story in the game [6]. The genre of a game is classified into 8 genres, namely Drama, Crime, Fantasy, Horror, 
Mystery, Science Fiction, War and Espionage, and Western/Eastern or Frontier.

The game is classified to help the game players identify, search for, and pick up the themes of interest in playing the games, which in this category can also Page | 98 determine the theme that the developers will choose to produce the games [7].

\section{B. Online Games}

Online games can usually be played by several players in different places. The connection between these players in the game uses an internet connection [8]. In other words, online game is computer or mobile game that uses an internet connection to process or interact between the game players.

On the other hand, offline game is the opposite of the online game, namely game that can only be played alone and cannot interact with other players.

Although there are some offline games that require an internet connection to play, but it is not to interact with other players. In this game, usually the internet connection is only used for authenticating the user logins, posting the rankings, or purchasing the premium contents from the server only. Therefore, the need for an internet connection in the game does not mean that the game is an online game.

\section{Game Platform}

Today, the media or platform for playing games is divided into 3 categories, namely Console, PC/Computer, and Mobile.

Included in the game consoles are Nintendo, SEGA, PlayStation, Xbox, with the characteristics of having a controller or joystick for playing the games.

Included in the PC games are the games that can be played using a computer or laptop, have features such as installing them on a PC, or can be played directly using a browser.

Meanwhile, included in the mobile games are the games that can be played using a mobile smartphone, tablet, or other devices.

\section{Related Work}

The research [9] analyzed the effect of the brand image on purchasing the contents from a Clash Royal game, a strategy game type. Nonetheless, it only focused on the brand image and used the perception of the brand image itself. It only used the perceptions of a player playing a game, without specifying a brand image in the game.
TABLE I

GAME TYPE PARAMETERS

\begin{tabular}{|c|l|}
\hline No. & Game Type \\
\hline 1. & Action \\
\hline 2. & Role Playing \\
\hline 3. & Simulation \\
\hline 4. & Strategy \\
\hline 5. & Sport \\
\hline 6. & Puzzle \\
\hline 7. & Idle Game \\
\hline
\end{tabular}

The research [10] analyzed the factors that could affect the interest in purchasing the contents in the mobile games. It conducted a survey to 400 people directly and indirectly to get the effect of purchasing the game contents with consideration of 5 factors, namely Product Factor, Support Factor, Game Experience, Social Influence, and Personality Trait. Based on the findings, the Social Influence and Personality Trait had the greatest impact.

\section{RESEARCH METHOD}

The research was conducted to determine the factors that could affect the game players' interest in purchasing the game contents and the money the game players spent to purchase the contents. Hence, there were several parameters deemed necessary to measure the amount of interest, namely: Game Type, Game Platform, Playing Duration, and Game Mode. By comparison, two parameters stated the purchase results, namely the experience of purchasing the game contents, and the amount of purchasing the game contents in rupiah currency.

This research used a survey in which there were 10 questions about the game players' experience in playing and doing top-up games with the parameters that had been provided. These questions referred to 4 parameters as the tester, and 2 parameters as the result to calculate the amount of purchasing the contents in the game.

This research referred to the seven genres, by providing a survey to the gamers about the game type played most often, and the game type made the most purchases in them. These parameters are as in the table below.

In this research, two research questions would be related to the game type played most often, and the game type where the contents were mostly purchased.

The game platform parameters were divided into three categories, namely, Game Console (Nintendo, SEGA, PlayStation, PSP, Game Boy, Wii, Xbox, and others), PC/Computer Game, and Mobile Game operated in Mobile Android/iOS, as in the table below. 
Based on the research [11] about the length of time the players played the games, it was divided into 4 categories, namely:

TABLE II

PLAYER BEHAVIOUR PLAYING GAME

Page | 99

\begin{tabular}{|c|l|l|}
\hline No & Hours Play & Category \\
\hline 1. & 0 hour/day & Non gamers \\
\hline 2. & $\begin{array}{l}\text { Less than } 1 \\
\text { hour/day }\end{array}$ & Infrequent gamers \\
\hline 3. & $1-2$ hour/day & Regular gamers \\
\hline 4. & $\begin{array}{l}\text { More than } 2 \\
\text { hour/day }\end{array}$ & Frequent gamers \\
\hline
\end{tabular}

In the length of time parameter, the players would be asked about how much time they spent playing the game in one day.

Nevertheless, the game play mode was divided into two categories, such as Online Game and Offline Game, namely the parameter related to the network assess in playing the game.

In the game mode parameter, the players would be asked about whether they preferred to play online or offline games.

Of the four parameters, a correlation would be made to the interest in purchasing the game contents in it with two questions given to the respondents.

The players were asked whether they had ever purchased the contents in the game. As in the research [12,13], from this survey several parameters would be processed using association rules to get the relationship with the factors that affected in purchasing the game contents [14].

By using the Association Rule, the relationship of the four parameters would be calculated one by one by combining 2 parameters and giving the highest results based on the Support and Confidence values.

In the figure below, the testing model would be carried out using the Orange data mining application

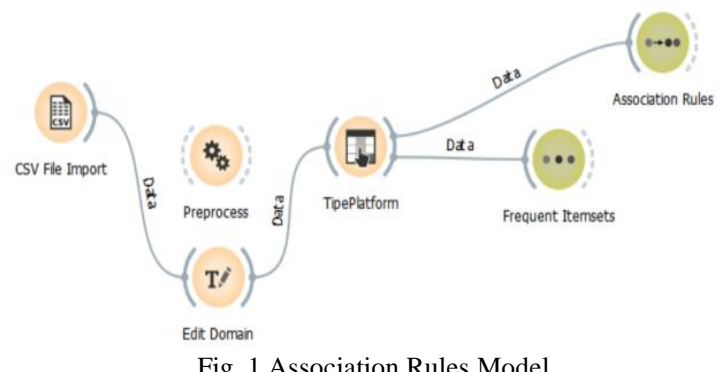

The model consisted of 3 parts, namely pre-processing data, calculating frequents item set and Association Rule.

\section{RESULT}

The survey was distributed to 455 respondents in Indonesia with the respondents' age range of around
18-30 years. Here are the results of the analysis of the association rule calculation.

\section{Effect of Game Characteristics on Purchasing Game Content Interest}

At this point, it analyzed the effect and relationship of the game type, game platform, and game mode on the interest in purchasing the game contents.

The explanation of the following table is in accordance with the association rules, support is the size of the population that belongs to the antecedent relationship. On the other hand, confidence is the percentage of the antecedent and consequent.

TABLE III

ASSOCIATION RULES RESULT TO FIND RELATIONSHIP WITH CONTENTS PURCHASING INTERESTS

\begin{tabular}{|l|c|c|c|}
\hline \multicolumn{1}{|c|}{ Antecedent } & Cons. & Supp. & Conf. \\
\hline Action - Online Games & Buy & 0.307 & 0.809 \\
\hline Action - Mobile Game & Buy & 0.212 & 0.760 \\
\hline PC - Online Games & Buy & 0.168 & 0.833 \\
\hline RPG - Online & Buy & 0.060 & 0.846 \\
\hline Action - PC & Buy & 0.056 & 0.909 \\
\hline Simulation - PC & Buy & 0.011 & 1.000 \\
\hline & & & \\
\hline $\begin{array}{l}\text { Simulation - Mobile } \\
\text { Game }\end{array}$ & No & 0.061 & 0.733 \\
\hline Puzzle - Offline & No & 0.156 & 0.966 \\
\hline Puzzle - Mobile Game & No & 0.173 & 0.969 \\
\hline Mobile - Offline Games & No & 0.268 & 0.787 \\
\hline
\end{tabular}

The table above shows the Indonesian players' characteristics. $30 \%$ of them had an interest in playing the games with the Action type. With interest in purchasing the contents in the action game, around $76 \%-90 \%$ of them were interested in purchasing the game contents.

For online RPG game, the interest in purchasing the contents was $84.6 \%$ with the population of $6.1 \%$. Different from that, the simulation game on the PC platform had $100 \%$ interest in purchasing the contents, but the population was small, only $1.1 \%$.

By contrast, in the Puzzle game, the players tended not to make purchases where the confidence of the Puzzle Mobile game had a 95.9\% chance of not purchasing the game contents.

\section{Effect of Player Behavior on Game Characteristics in Purchasing Game Content Interest}

At the following point, it analyzed the player behavior in relation to the game characteristics towards the interest in purchasing the game contents in it. 
TABLE IV

THE RESULTS OF TESTING THE RELATIONSHIP BETWEEN PLAYER BEHAVIOR AND INTEREST IN PURCHASING THE GAME CONTENTS

\begin{tabular}{|l|c|c|c|}
\hline \multicolumn{1}{|c|}{ Antecedent } & Cons. & Supp. & Conf. \\
\hline Regular - Action & Buy & 0.719 & 0.711 \\
\hline Regular - Online & Buy & 0.207 & 0.712 \\
\hline Frequent - Online & Buy & 0.208 & 0.949 \\
\hline Frequent - Action & Buy & 0.145 & 0.929 \\
\hline Frequent - PC & Buy & 0.112 & 0.909 \\
\hline Frequent - Mobile & Buy & 0.112 & 0.870 \\
\hline Frequent - RPG & Buy & 0.095 & 1.000 \\
\hline Regular - PC - & Yes & 0.061 & 0.733 \\
\hline $\begin{array}{l}\text { Infrequent } \\
\text { Online }\end{array}$ & No & 0.056 & 0.714 \\
\hline $\begin{array}{l}\text { Infrequent } \\
\text { Offline }\end{array}$ & No & 0.207 & 0.881 \\
\hline $\begin{array}{l}\text { Infrequent } \\
\text { Mobile }\end{array}$ & No & 0.140 & 0.962 \\
\hline $\begin{array}{l}\text { Infrequent } \\
\text { Puzzle }\end{array}$ & & & 0.872 \\
\hline
\end{tabular}

From the table above, it can be concluded that the number of the Indonesian game players was the Regular type and preferred the Action game with the support of $71.9 \%$.

The interest in purchasing the game contents was affected by the length of time the players played the game itself. For the frequent players, their interest in purchasing the game contents was $87 \%$ to $100 \%$ for the games with the Action and RPG categories. On the other hand, for the Regular Players, their interest in purchasing the game contents was equal to $71 \%$ $73 \%$.

In contrast, for the Infrequent Players, the had great interest in not purchasing the game contents by $71 \%-96 \%$, especially for the Offline and Puzzle games.

\section{CONSCLUSION}

1. From the results of the analysis in the previous point, it was found that the greatest interest in purchasing the contents was made by the players with the Frequent Player category, especially in the Action game, Online game, and RPG game.

2 . The Indonesian game market was dominated by the players in the Regular Player category who played the Action game, where they were interested in purchasing the contents, especially for the Action game, and Online game.

3. Many Indonesian players had no interest in purchasing the game contents on the Puzzle Game and Offline Game. The potential for developing the Action game, online game, and RPG game in Indonesia was very large since they were supported by the interest in purchasing the game contents from the players.

\section{REFERENCE}

[1] AR.R.T Hidayat and A Y Asmara 2017. Creative industry in supporting economy growth in Indonesia: Perspective of regional innovation System. IOP Conf. Ser: Earth Environ. Sci.70 012031

[2] H. Wong, 2014. A Study of The Video Game Industry In U.S Metropolitan Areas Using Occupational Analysis. Zhurnal Eksperimental Noi i Teoreticheskoi Fiziki

[3] Warman, Peter. 2017. Newzoo Global Game Market Report. Global Mobile Games Conference: London

[4] Prasetio, Eko Agus, Yuana, Rivira and Anggarini, LT. 2020. Increasing Technology- Based Startup Grant Effectiveness. International Journal of Innovation, Creativity and Change, Vol. 11, Issue 12020

[5] Gularso, Kurnadi, Mursitama, T.N., Heriyanti, P, and Simatupang, Boto. 2020. Disruptive Business Modle Innovation in Indonesia Digital Startup. Social Science \& Humanities, Pertanika.

[6] Lindsay, Grace. 2005. Game Types and Genre. University of Miami 2005.

[7] Clarke, Rachel I., Lee, Jin Ha, and Clark, Neils.2015. "Why Video Game Genres Fail: A Classificatory Analysis" (2015). School of Information Studies - Faculty Scholarship. 167.

[8] Wang, Meng. 2018. Online Games Virtual Products-Transaction and Value. International Conference on Management, Economics, Education and Social Sciences (MEESS 2018)

[9] Jeremy, Limanto et all. 2018. Factors Affecting the Purchase Intention of Virtual Goods in Mobile Game Clash Royale. Petra International Journal Of Business Studies, Vol. 1, No. 1, June 2018: 45-56

[10] Zheng Zhang, Thotsapon Sortrakul. 2015. Proceedings of The IRES 11 th International Conference, Bangkok, Thailand, 4 th October 2015, ISBN: 978-93-85832-07-9

[11] IP, Barry.2008. Gaming frequency and academic performance. Australasian Journal of Educational Technology 2008, 24(4), 355-373

[12] Cheng-Hsun Ho and Ting-Yun Wu. 2012. Factors Affecting Intent To Purchase Virtual Goods In Online Games

[13] Suchacka, Grazyna. 2016. Using Association Rules to assess purchase probability Online Store. Inf Syst E-Bus Manage. DOI 10.1007 /s10257-016- 0329-4

[14] Edwar, $M$ et all. 2018. The Factors That Affecting the Product Purchasing Decision Through Online Shopping By Students of Surabaya State University. International Journal of Educational Research Review 